\title{
Does value added of intellectual capital influence voluntary disclosure? The moderating effect of CSR practices
}

\author{
Jamel Chouaibi ${ }^{1, a}$ and Salim Chouaibi ${ }^{\mathrm{a}}$ \\ ${ }^{a}$ Faculty of Economics and Management of Sfax, University of Sfax, Tunisia
}

\begin{abstract}
Research Question: Does the effect of corporate social responsibility (CSR) practices and value added of intellectual capital (VAIC), is contingent on the intellectual capital (IC) information disclosure policy adoption in the Environmental, Social and Governance (ESG) companies? Does CSR have a moderating effect on the relationship between VAIC and IC disclosure?

Motivation: The majority of the literature has examined the effect of value added and social responsibility on the overall transparency of the business while neglecting their effect on the voluntary intellectual capital disclosure. Our study seeks to fill this gap by testing the moderating effect of socially responsible practices on the relationship between VAIC and voluntary IC disclosure. This paper is the first comprehensive attempt to analyses the interaction between CSR practices and VAIC with voluntary IC disclosure.

Idea: This study examines how CSR practices moderate the relationship between the added value of intellectual capital (VAIC) and voluntary disclosure of IC in the world's most committed ESG companies in business ethics.

Data: The data were collected from Thomson Reuters ASSET4 database from four countries to analyze data of 153 listed companies selected from the Environmental, Social and Governance (ESG) index between 2015 and 2019.

Tools: To test study's hypotheses, we applied linear regression with a panel data using the Thomson Reuters ASSET4 database.

Findings: Two main results can be derived: First, the integration of CSR into company strategy is positively associated with voluntary IC disclosure. Second, the interaction between CSR practices and VAIC is a determinant of this type of disclosure to reduce the asymmetry of information and the conflict of interest.

Contribution: The majority of the literature has examined the effect of value added and social responsibility on the overall transparency of the business while neglecting their effect on the voluntary intellectual capital disclosure. Our study seeks to fill this gap by testing the
\end{abstract}

${ }^{1}$ Corresponding author: Jamel Chouaibi, Department of Accounting, Faculty of Economics andManagement of Sfax, Tunisia, Tel. (+216) 53745754, email addresses: chouaibi_jamel@yahoo.fr 
moderating effect of socially responsible practices on the relationship between VAIC and voluntary IC disclosure. This paper is the first comprehensive attempt to analyses the interaction between CSR practices and VAIC with voluntary IC disclosure.

Keywords: corporate social responsibility (CSR), moderating effect of CSR, value added of intellectual capital (VAIC), voluntary disclosure, Intellectual Capital (IC).

\section{JEL codes: M41}

\section{Introduction}

Over the last several decades knowledge issues regarding investment decisionmaking has attracted increasing attention of academicians and researchers. Obviously an organization does not only derive its wealth from its securities and financials, but also from other immaterial elements, such as its reputation on the market, the skills of its employees, its relations with customers as well as its novelty in technology, etc. Consequently, with the emergence of the knowledge-based economy, we have witnessed many changes in the nature of work and the demands placed on organizations to become the storehouses of innovation, nourishing and sustaining wellsprings of talent (Seleim et al., 2004; Lin et al., 2015; Luthan et al., 2016; Salvi et al., 2020).

In this environment, the interaction between CSR and the intellectual capital efficiency among companies operating in the ESG index represents a fundamental element for the definition of a new growth model, which, by integrating social, economic and governance efficiency, is able to grant companies the ability to withstand competitive pressures and contribute to sustainability. The performance of a firm is highly influenced by the components of intellectual capital that are probably more risky than industrial assets due to the fact that their contribution to the business results is difficult to measure and evaluate. In order to limit these problems of identification and measurement, the ESG companies choose voluntary disclosure to reduce the asymmetry of information with regard to this subject. This view is based on the premise that there are inherent conflicts and tensions among various stakeholders as different groups of stakeholders have disparate objectives. Left unresolved, these conflicts are likely to hurt firm performance. CSR activities are adopted to mitigate the conflicts (Ongsakul et al., 2020). Environmental, Social and Governance (ESG) is captured in this paper as an index used as a proxy of firms' engagement on CSR activities (Peters \& Romi, 2013; Fatemi et al., 2017; Alipour et al., 2019; Wong \& Kim, 2020), which is provided by ASSET4® database of DataStream, by Thomson Reuters Inc., the world's leading source of intelligent information for businesses and professionals. The index of ESG firms is objectively 
and consistently defined measures permitting like-for-like measurement of firmspecific CSR activities.

The risk inherent in the representation and accounting measurement of IC components has recently become a hot topic of research. The determinants of IC information disclosure, lies at the heart of the major concerns of the various stakeholders of the company. Thus, an extensive theoretical and empirical literature has investigated the role of CSR practice in the accounting information quality (Barniv and Myring, 2006; Chan et al., 2009; Hu et al., 2012; Ball et al., 2015; Karim et al., 2016; Fatemi et al., 2017; Wellalage et al., 2019).

Moreover, the effect of the value added of intellectual capital (VAIC) on voluntary disclosure remains an under-researched subject in accounting and financial literature. Despite the increasing recognition of the intellectual capital in driving the firm's value and competitive advantage, an appropriate measure of the firm's intellectual capital is still theoretical (Salvi et al., 2020). A research conducted by Pulic (1998) and Salvi et al. (2020), showed that the capital employed and the intangible capital are correlated with the firm's market value. Instead of directly measuring the firm's intellectual capital, Pulic (2000) proposed a measure of the efficiency of the intellectual capital (the Value Added Intellectual Capital (VAIC). The major components of the VAIC can be defined according to the firm's resources. We can list among these components the physical capital, the human capital and the structural capital. The VAIC method is used to provide information about the value creation efficiency of tangible and intangible assets of a company. The main components of VAIC in research conducted by Pulic (1998) and Mohammad \& Bujang (2019) are Human Capital Efficiency (HCE), Capital Employed Efficiency (CEE), and Structural Capital Efficiency (SCE).

In recent years, the quality of the information published by firms on their IC has attracted particular interest in accounting research. In this regard, concerns about the effect of added value by corporate intellectual capital and corporate social responsibility (CSR) practices on the quality of information disclosed voluntarily have been growing since the emergence of the financial scandals that have marked the world of business. These financial scandals have raised an important question about the relevance and reliability of data published by companies following the bankruptcy of a company or the disclosure of an accounting fraud: Is it still viable to trust the accounting information of the company, especially with an intellectual capital difficult to identify and measure?

Indeed, the information asymmetry between the CEO and the users of financial information has become increasingly huge (Barth et al., 2001). This has triggered a debate about the relevance of traditional accounting information to intellectual capital and its contribution to the process of value creation and corporate image (Lev et al., 2005; Abeysekera, 2008; Vitolla et al., 2020). Based on these premises, the 
main purpose of this paper is to combine these new roles of CSR practice in the strategy of ESG Company and analyze the effect of socially responsible engagement on IC transparency. The research question that this paper is based on is repeated below to merit further discussion and formulation of hypotheses: Does the effect of CSR practices and VAIC, is contingent on the intellectual capital information disclosure policy adoption in the ESG companies?

In addition, another debate has been centered on the effect of the added value of intellectual capital on the voluntary disclosure of information on these intangible assets in order to reduce the asymmetry of information. Several researchers note that the poor relevance of the IC information disclosed is due to the difficulty of identifying and measuring IC in the analysis of the financial situation of the company (Lev et al., 2005; Ashton, 2005; Vitolla et al., 2020).

As a result, the relationship between VAIC, CSR and voluntary IC disclosure is a little complicated. In fact, ESG companies implicated in the knowledge-based economy are voluntarily engaged in the process of disclosing information about the components of IC in order to meet the requirements of financial transparency. Thus, we aimed to answer the following question: does CSR have a moderating effect on the relationship between VAIC and IC disclosure?

Corporate social responsibility (CSR) constitutes a crucial area of research that spans several disciplines, including management, finance, accounting and marketing. Our results show that the socially responsible engagement increases the IC disclosure. Our findings reveal that, in this context, CSR practices and value added of intellectual capital is a determining factor in IC disclosure. In addition, the result shows that the moderating effect of CSR is significant. Therefore, this study highlights the importance of CSR practices for corporate that intends to take into account the interests of the various stakeholders of the company. Our study makes several contributions to the literature. We contribute to the existing literature on CSR practices and its moderator effect on the relationship between values added of intellectual capital and voluntary disclosure utilizing panel data that expand into international perspective. This research is a useful complement to the existing understanding of CSR, its structure and implementation, and the involvement of business leaders in its development and institutionalization. This study, as a practical research, was intended to critically examine the existing knowledge on CSR and its effect in the voluntary IC disclosure. As part of its journey, this research explores the relationships between various theoretical concepts and empirical correlations with the aim of building a clearer picture of the field and connecting managerial theories and practices. Our research offers the information user a vision to better assess the transparency of the company as well as the quality of the information disclosed on its environment and its future growth opportunities in a context where the approach of CSR practices occupies a central position in business valuation. 
The remainder of this paper is organized as follows: Section 2 presents the basic theoretical background and the hypotheses developed. In this section, we test the relationship between value added of intellectual capital and the effect of the socially responsible practices on the voluntary IC disclosure. Section 3 outlines the methodology used in this study. As for the empirical results, they are presented and discussed in section 4. Finally, the discussions of our findings and their implications as well as the concluding remarks are given in section 5 .

\section{Literature review and hypotheses development}

Previous literature has investigated different facets of IC disclosure. In this context the present work aimed to study the effect of the added value of the intellectual capital (VAIC) of companies on the voluntary IC disclosure on the one hand and on the interaction between CSR and the VAIC and its effect on the voluntary IC disclosure on the other hand. Therefore, we begin our review of the literature by discussing the theoretical and empirical studies conducted on this research topic.

\subsection{Effect of value added of intellectual capital of ESG companies on voluntary IC disclosure}

An in-depth reading of the literature on the economic consequences of voluntary disclosure of information shows that it is a topic of considerable interest for companies because of its effect on their economic performance. In this respect, the synergy between the different components of the company's intellectual capital is a motivation that the company to adopt a voluntary disclosure policy in order to ensure transparency and legitimacy. This is explained by the fact that the financial statements are still insufficient to measure VAIC due to the wide gap between the prices of companies' shares and the book value obtained from their balance sheets (Özer \& Çam, 2016). As a result, the lack of exact comparability between the market value of an enterprise and its carrying amount adds to the doubt about the relevance of the accounting data published in the financial statements. At this level, the voluntary disclosure of IC information is considered as a major solution to reduce the gap between what is real and what is accounting (Vitolla et al., 2019; Salvi et al., 2020). Historically, the subject of disclosure is extremely common in the international accounting debate as it is a key element in understanding a company's financial statements. Indeed, Lambert et al. (2011) argue that understanding the economic consequences of information disclosure can explain the gap between the market value and the accounting value of the company. Thus, the recognition of VAIC can be the basis for improving the quality of the disclosure made by the company. In this respect, the company that achieves a high VAIC seeks to reflect this performance in its financial report by applying a policy of voluntary communication. In addition, in order to reduce agency costs and information asymmetry issues, companies that properly value their IC tend to disclose quality 
information that reflects the effect of synergy between IC components. In this context, previous studies have found that companies that benefit from their intellectual capital adopt a process of voluntary disclosure on its performance factors. Although a large number of studies have attempted to find an answer to this problem, the results are still mixed. Abeysekera (2011) found that insofar as the resources of intellectual capital are considered determinants of future profits, investors believe that the level of uncertainty is higher for these resources than for the assets presented in the financial statements. This view is reflected in the differential treatment for IC components as well as for the value added by each component. Thus, VAIC has a determining effect on voluntary IC disclosure.

In addition, the financial crisis has shown weaknesses in the recoverable value of certain intangible assets (for example, goodwill). Similarly, the financial statements have shown a lack of information concerning these assets and consequently the question of the development of measurement models that better explain the invisible or hidden values of companies obliges various companies to develop a framework for IC information disclosure to reflect its values added.

Ferchichi and Paturel (2013) postulate that intellectual capital is a resource for the company and must accordingly be managed as a driver of voluntary disclosure. Similarly, Bchini (2015) argues that since IC plays a larger role in the creation of market value, it seems interesting to note that voluntary disclosure is becoming increasingly important in today's knowledge-based economy to ensure transparency. In this respect, the disclosure of information on the firm's IC has become one of the factors of wealth production. As a result, there is a growing need to develop new methods that take into account IC such as voluntary IC disclosure (Berzkalne \& Zelgalve, 2014; Albertini \& Fabienne, 2019; Salvi et al., 2020). In an international context, Abeysekera (2011) finds that the degree of uncertainty associated with IC resources can be mitigated by greater disclosure of their potential for future earnings. In addition, Botosan (2006) finds that the results of the causal relationship between IC and disclosure are generally mixed and suggests that IC disclosure varies according to the type of information. This was confirmed by Berzkalne and Zelgalve (2014), have criticized the relationship between the market value and the book value: it is necessary to have changes in the accounting practices to appreciate the VAIC. Thus, it is argued that the coefficient of VAIC positively influences the voluntary IC disclosure. Ozkan et al. (2016) argue that IC can be defined as intangible assets that are not explicitly listed on a firm's balance sheets, but have a positive impact on the firm's performance. Furthermore, the company's executive discloses the added value of its intellectual capital to reflect mainly the company's good reputation to its stakeholders.

On the basis of what has been developed, we can see that the coefficient of the VAIC positively influences the voluntary IC disclosure. Thus, we formulate this hypothesis. 
H1. The coefficient of VAIC has a positive impact on the extent of voluntary IC disclosure.

\subsection{The effect of corporate social responsibility on the voluntary IC disclosure}

It may be useful for researchers to highlight the evolution of studies on the relationship between CSR and the behavior of market investors in order to understand the need for an ethical and behavioral approach to finance. In addition, the economic value of the enterprise lies not only in its means of production, but also in the social action of its intellectual capital to implement the material and human resources necessary for profitability. Hence the need for a new corporate strategy based on the concept of social responsibility encompassing the objectives of the company and its environment to ensure sustainable development (Elvira et al., 2016). Indeed, all companies are increasingly invited to be socially responsible to meet the needs of its stakeholders. As a result, these companies have incorporated these practices into management and accounting systems to improve their information disclosure practices in a detailed and informative manner (Karim et al., 2016).

Elvira et al. (2016) highlighted a positive relationship between social responsibility and the quality of disclosed information and found that disclosure of information in a detailed manner is conditional on the existence of socially responsible practices. They also suggest that there is a positive relationship between the level of disclosure and CSR practices and conclude that increased disclosure is a form of socially responsible behavior. Similarly, Sun et al. (2010) finds that companies that pursue a strategy of voluntary IC disclosure are brought to value CSR actions and practices. This is interpreted positively by the different stakeholders through its effects on the decisions taken by the company, on the behavior of the manager and on the legitimacy of the ESG Company.

In addition, in the light of previous studies, CSR, through its effect on the behavior of the leader, is a solution for conflicts of interest and the asymmetry of information existing between the stakeholders of the company. Furthermore, García-Sánchez et al. (2016) claim that in an uncertain world, adopting a CSR strategy could help reduce uncertainty. Similarly, some researchers argue that CSR is a very broad and unrestricted area and that voluntary disclosure of information is an act of this societal responsibility. Thus, being socially responsible does not only mean fulfilling legal obligations, but also going further and investing more in the environment to ensure the sustainability of the business and its business objectives (Thorpe, 2013; Murashima, 2020). A study by Fassin et al. (2014) on the European Union states that CSR is "a concept whereby companies voluntarily decide to contribute to the achievement of a better society and a cleaner environment". In other words, the 
principle of social responsibility is an asset for the company and the various actors because of its effect on the relevance of the information provided by the company on their intellectual capital. Karim et al. (2016) studied the effect of social responsibility on the quality of the information disclosed in companies' annual reports. They found a positive relationship between the level of disclosure and CSR practices and concluded that greater disclosure was a form of socially responsible behavior.

Thus, to limit agency problems and signal the quality of the company and its intellectual capital, we assume that business leaders are encouraged to incorporate socially responsible practices into the information disclosure strategy, such as the adoption of a voluntary IC disclosure policy. Therefore, our second assumption is formulated as follows:

H2. Corporate social responsibility has a positive impact on the extent of IC voluntary disclosure.

\subsection{The moderating effect of CSR on the relationship between VAIC and voluntary IC disclosure}

The integration of the moderating effects of the variables related to the characteristics of the CEO has been the subject of a number of researches in social accounting. These variables include: age, gender, experience and education (Campbell \& Mínguez, 2008; Brieger et al., 2019). However, we note the lack of integration of the moderating effect of behavioral variables. In this respect, our objective was to study the influence of the interaction between socially responsible practices and the added value of intellectual capital on the disclosure of IC information. The business practice with CSR indicates that, from an economic perspective, there is empirical evidence supporting the conjecture that engaging in social activities diminishes risk and consequently costs, relating to an investment (Jensen, 2002; Karim et al., 2016; Wellalage et al., 2019). For example, the reduction of the information asymmetry, CSR is frequently used as a blanket term referring to organizations' responsibility to society. Liang \& Renneboog (2017) are more cautious, suggesting that CSR focuses on firm activities that improve social welfare. Thus, we talk about the integration between socially responsible practices and the intellectual capital resources of the company to ensure performance and transparency.

The goal of social responsibility is to create higher standards of living for stakeholders inside and outside the company while preserving the profitability of the business. For example, Stubbs and Rogers (2013) suggest that the positive market response to disclosure of information, according to the principles of social responsibility, encourages the company to increase their stock prices. Su et al. (2016) 
define CSR as the inclusion of environmental, social and governance concerns in corporate decision-making. Thus, it is argued that disclosure in the light of social practices is an asset for the company (Said et al., 2009; Gery Djajadikerta \& Trireksani, 2012; Sutantoputra et al., 2012; Martínez-Ferrero et al., 2016). In addition, a meta-analysis by Škare \& Golja (2014) concludes that the existing results indicate a positive association between socially responsible activities and the financial activities of the firm. CSR is increasingly important in promoting the message that business needs to be concerned with not just profit but also credibility (Gamerschlag et al., 2011; Elvira et al., 2016; Fatemi et al., 2017). Jamali and Mirshak (2007) find that strategic CSR is strategic philanthropy aiming to achieve strategic business goals while also promoting societal welfare. This reinforces our proposition that corporate social responsibility moderates the relationship between VAIC and voluntary IC disclosure.

H3. Corporate social responsibility moderates the relationship between and VAIC and the voluntary IC disclosure.

\section{Research methodology}

The methodology used in this field - quantitative versus qualitative - can refer to several things, especially data, or techniques for collecting and processing such data. Hence, Data collection methods are diversified. The qualitative technique is sometimes used in previous studies, but the practice of this technique is too difficult in the international context. In this study we focus on a quantitative method.

In what follows, we will describe the sample, the tools and procedures applied for data collection and the empirical model.

\subsection{Sample selection}

It should be noted that the main purpose of this article was to study the effect of the interaction between CSR and VAIC on the voluntary IC disclosure. As a result, only companies involved in social processes are eligible for this research work. In other words, the choice of the sample was conditioned by the commitment and participation of companies in the Environmental, Social and Governance (ESG) process. Our data was obtained from the ASSET4 database (Data Stream) and other data sources, such as the annual reports. The American research institute ASSET4 analyzes the global market to identify sector by sector, the companies most committed to the process of professional ethics and CSR practices. Then, a list of the most socially responsible companies in the world is published every year in the ESG index. This is considered one of the most recognized indices in the world. As a result, our sample was chosen as follows. The initial population consisted of 438 companies in the ESG index that was candidates for the ASSET4 database from four countries. 
In a second step, companies whose supplied data are not available were excluded from the sample (268). From the 170 best ranked companies, we excluded firms that are part of the financial sector, i.e. 17 companies. Therefore, our final sample encompassed 153 firms selected from the ESG index and observed between 2015 and 2019. In other words, a total of 765 firm-years observations. Our sample selection is summarized in Table 1. Panel A describes the sample selection, Panel B provides the distributional properties of the full sample by country and Panel C presents sample distribution by industry.

Table 1. Sample selection and breakdown by country and industry

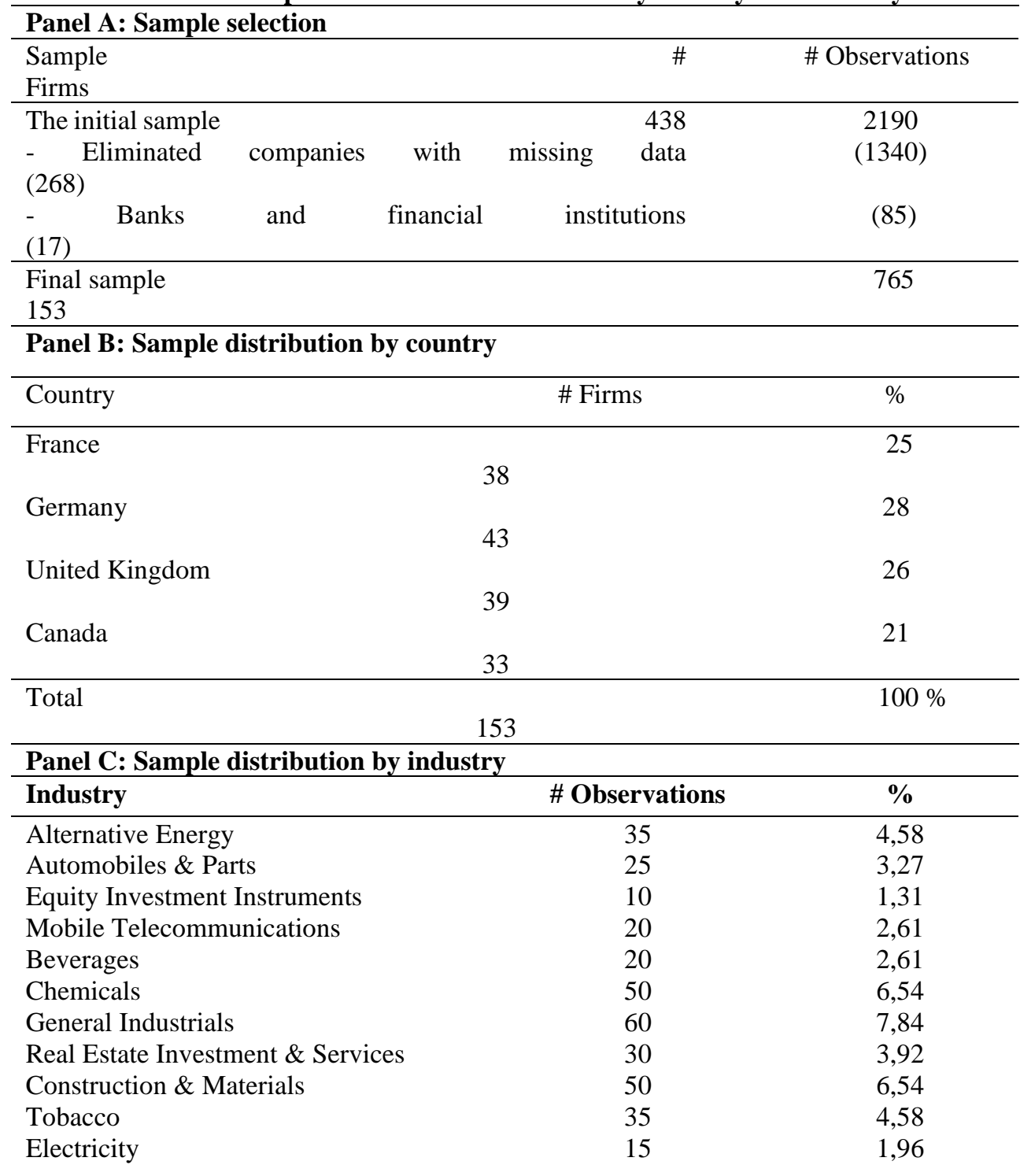




\begin{tabular}{lcc} 
Electronic \& Electrical Equipment & 20 & 2,61 \\
Fixed Line Telecommunications & 25 & 3,27 \\
Food Producers & 30 & 3,92 \\
Gas, Water \& Multiutilities & 25 & 3,27 \\
General Retailers & 20 & 2,61 \\
Health Care Equipment \& Services & 25 & 3,27 \\
Industrial Engineering & 30 & 3,92 \\
Industrial Metals \& Mining & 40 & 5,23 \\
Leisure Goods & 15 & 1,96 \\
Mining & 30 & 3,92 \\
Oil \& Gas Producers & 45 & 5,88 \\
Pharmaceuticals \& Biotechnology & 35 & 4,58 \\
Real Estate Investment Trusts & 35 & 4,58 \\
Software \& Computer Services & 25 & 3,27 \\
Technology Hardware \& Equipment & 15 & 1,96 \\
\hline Total & 765 & 100 \\
\hline
\end{tabular}

Notes: Panel A describes the sample selection, Panel B provides the distributional properties of the full sample by country, and Panel C presents sample distribution by industry. \# Observations: is the total of firm-years observations by industry.

\subsection{Variables measurement}

Our methodological approach was carried out by a measurement of the variables, which was followed by model presentation to test the study hypotheses.

\subsubsection{Dependent variable "DISC_SCORE"}

The requirement of a firm's financial transparency, which is part of the framework of ESG practices, requires companies to adopt a voluntary disclosure policy, especially with regard to IC and its components. Consequently, financial transparency is a necessary condition for companies involved in the CSR practices. Based on a review of the theoretical and empirical literature on IC disclosure, we found that there are several measures used in different contexts.

To measure IC disclosure variable, Li et al. (2008) adopted the content analysis method which consists of analyzing the annual reports of companies in order to derive the qualitative, quantitative, financial as well as the non-financial data relating to their intellectual capital.

As part of our analysis, we adopted the measure used by Li et al. (2008, cited by Maaloul and Zeghal, 2015) on the qualification of IC items published by companies. In other words, based on the reading of the annual reports, we tried to verify whether the company has disclosed IC information. We built a disclosure index for each 
company based on a notation that carries 1 if the company discloses an item and 0 otherwise (for details see Appendix A).

\subsubsection{Independent variables}

Several categories of explanatory variables can be used to test their effects on the voluntary IC disclosure. We also tested the effect of two explanatory variables, namely the VAIC and CSR and subsequently the effect of the interaction between these two variables on IC disclosure.

\section{The value added of intellectual capital "VAIC"}

The VAIC has been used as a measure of the corporate intellectual ability Pulic (2000). Firer and Williams (2003) pointed out two advantages of the VAIC, which are providing an easy to calculate, standardized, and consistent basis of measure and enabling effective comparative analyses across firms and countries. The data used in the calculation of the VAIC are based on financial statements (Zeghal \& Maaloul, 2010). The procedures in calculating the VAIC are as follows: it is necessary to first define, specify and clarify the two basic concepts of value added (VA) and the value added of intellectual capital (VAIC) and its various components.

VA is calculated as the difference between outputs and inputs of the production process. We consider outputs to be all operating revenues, with the exception of operating revenues. However, inputs are external loads. This method of calculation is chosen because it is the most practical one.

$$
\text { VA= OUTPUT-INPUT }
$$

The Value Added of Intellectual Capital (VAIC) coefficient was presented by Chen Goh (2005) from a stakeholder theory perspective. The VAIC method provides a standardized and consistent basis of measurement. It decomposes intellectual capital into three independent variables, namely Human Capital Efficiency (HCE) Ratio, Structural Capital Efficiency (SCE) Ratio and Employed Capital Efficiency (ECE) Ratio. The VAIC represents the sum of the three variables.

The Human Capital Efficiency Ratio (HCE): It is calculated as the ratio of added value to the cost of human capital (HC). With $\mathrm{HC}$ is the sum of the expenses of the total number of employees of the company, including healthcare expenses and social security.

$$
\mathrm{HCE}=\mathrm{VA} / \mathrm{HC}(2)
$$


Employed capital Efficiency ratio (ECE): it is determined as the ratio of value added (VA) to capital employed (CE).

$$
\mathrm{ECE}=\mathrm{VA} / \mathrm{CE}(3)
$$

The structural capital efficiency (SCE) coefficient: it is calculated as the ratio between structural capital (SC) and value added (VA).

$$
\mathrm{SCE}=\mathrm{SC} / \mathrm{VA}(4)
$$

The structural capital is determined as the difference between value added and expenditure on personnel.

VACI: represents the fundamental basis for measuring intellectual capital and is calculated by adding the above three efficiency components.

$$
\mathrm{VAIC}=\mathrm{ECE}+\mathrm{HCE}+\mathrm{SCE}(5)
$$

\section{Corporate social responsibility "CSR_INDEX"}

The last two decades have witnessed a dramatic increase in CSR practices. A measure developed by Dias et al. (2017) who built a list of indicators to control of CSR practices disclose by company, comprised three CSR dimensions and 40 individual CSR indicators (5 economic, 20 social and 15 environmental). In our analysis, we measured corporate social responsibility «CSR_INDEX» by an index determined and calculated by the ASSET4 database to ensure comparability between companies. ASSET4 collects a detailed database on the assessment of the company's performance in the areas of environmental, social and corporate governance. Social CSR addresses issues concerning employees, customer, and local community. Environmental CSR includes issues related to interests of global or local community concerns. We think the CSR composite index computed from the Thomson Reuters ASSET4 database connects with what we want to examine for the relationship between CSR and intellectual capital voluntary disclosure. The CSR index is a measure of CSR performance at the firm level. ASSET4 strictly uses publicly available information such as sustainability reports, company websites, annual reports, attorney filings as well as messages from all major suppliers (Thomson Reuter Data Collection and Assessment Methodology, 2012).

In the ASSET4 database, the CSR index is an equally weighted composite index of three elements: society, environment and corporate governance. Social performance (CSR_S) covers seven categories: quality of employment; health and safety; training and development; variety; human rights; corporate community involvement; and 
product liability. Environmental performance (CSR_E) consists of three categories: resource reduction; emission reduction; and product innovations. The exercise of corporate governance covers five categories: management structure; compensation policy; board functions; shareholders' rights; and vision and strategy (Choi et al., 2018). Appendix B provides detailed information on the overall CSR index, as well as its three sub-indices.

Several researches, including experimental ones, have integrated one or more control variables to eliminate or mitigate its effect on the dependent variable. Indeed, the inclusion of a control variable in a model is purely technical and not conceptual, i.e. the control variable is never hypothesized. For example, the size of the company can be mentioned as a very frequent variable in management and accounting work. In our study, we integrated several control variables regardless of the characteristics of the company or its environment.

Thus, we retain as control variables: pollutant sector (POL_SECTOR), the leverage level (LEVE), the degree of innovation intensity (INVT) and the percentage of women in the board of directors (WOM_BOARD). For the variables related to environment of the firm, we used the legal system (LEG_SYST) because the companies of our sample belong to several countries.

For more details on measuring control variables, we define all the variables in our model in Table 2:

Table 2. Description of Variables

\begin{tabular}{|c|c|c|c|}
\hline Variables & Symbols & Measures & Sources \\
\hline $\begin{array}{l}\text { Voluntary } \\
\text { disclosure } \\
\text { index on } \\
\text { intellectual } \\
\text { capital } \\
\end{array}$ & DISC_SCORE & $\begin{array}{l}\text { Composite index of voluntary } \\
\text { disclosure of intellectual capital } \\
\text { calculated on the basis of a } \\
\text { combination of several items. }\end{array}$ & $\begin{array}{l}\text { The annual } \\
\text { reports }\end{array}$ \\
\hline $\begin{array}{l}\text { Added Value } \\
\text { of Intellectual } \\
\text { Capital }\end{array}$ & VAIC & $\begin{array}{l}\text { Value added (VA) is calculated } \\
\text { as the difference between } \\
\text { outputs and inputs of the } \\
\text { production process. }\end{array}$ & $\begin{array}{l}\text { Thomson } \\
\text { Reuters } \\
\text { ASSET4 } \\
\text { (Datastream) }\end{array}$ \\
\hline $\begin{array}{l}\text { Corporate } \\
\text { social } \\
\text { responsibility }\end{array}$ & CSR_INDEX & $\begin{array}{l}\text { It is an index developed by } \\
\text { ASSET4 which consists of a } \\
\text { series of items that count the } \\
\text { CSR of companies. }\end{array}$ & $\begin{array}{l}\text { Thomson } \\
\text { Reuters } \\
\text { ASSET4 } \\
\text { (Datastream) }\end{array}$ \\
\hline $\begin{array}{l}\text { The effect of } \\
\text { the interaction }\end{array}$ & VAIC*CSR_INDEX & $\begin{array}{l}\text { The interaction between the } \\
\text { CSR and the VAIC }\end{array}$ & $\begin{array}{l}\text { Thomson } \\
\text { Reuters } \\
\text { ASSET4 } \\
\text { (Datastream) }\end{array}$ \\
\hline
\end{tabular}


Does value added of intellectual capital influence voluntary disclosure?

The moderating effect of CSR practices

\begin{tabular}{|c|c|c|c|}
\hline Variables & Symbols & Measures & Sources \\
\hline $\begin{array}{l}\text { The degree of } \\
\text { innovation } \\
\text { intensity }\end{array}$ & INVT & $\begin{array}{l}\text { Is the ratio between the research } \\
\text { and development costs and the } \\
\text { turnover achieved during the } \\
\text { years } 2015 \text { to } 2019 \text {. }\end{array}$ & $\begin{array}{l}\text { Thomson } \\
\text { Reuters } \\
\text { ASSET4 } \\
\text { (Datastream) }\end{array}$ \\
\hline Leverage & LEVE & $\begin{array}{l}\text { The level of indebtedness is the } \\
\text { ratio between long-term and } \\
\text { medium-term debts and total } \\
\text { assets. } \\
\text { Debt ratio } \mathrm{N}(\mathrm{END})=\text { Debts in } \\
\text { the long and medium term / } \\
\text { Total assets }\end{array}$ & $\begin{array}{l}\text { Thomson } \\
\text { Reuters } \\
\text { ASSET4 } \\
\text { (Datastream) }\end{array}$ \\
\hline $\begin{array}{l}\text { Percentage } \\
\text { women on } \\
\text { board of } \\
\text { directors }\end{array}$ & WOM_BD & $\begin{array}{l}\text { We measured female } \\
\text { involvement in the board as the } \\
\text { proportion of women on the } \\
\text { board (female director ratio). } \\
\text { We then divided the number of } \\
\text { women board members by the } \\
\text { total number of board members } \\
\text { to calculate the female director } \\
\text { ratio }\end{array}$ & $\begin{array}{l}\text { The annual } \\
\text { reports }\end{array}$ \\
\hline $\begin{array}{l}\text { Pollutant } \\
\text { sector } *\end{array}$ & POL_SECT & $\begin{array}{l}\text { The pollutant sector is a binary } \\
\text { variable that takes the value of } 1 \\
\text { if the company belongs to the } \\
\text { polluting sectors and } 0 \\
\text { otherwise. }\end{array}$ & $\begin{array}{l}\text { Thomson } \\
\text { Reuters } \\
\text { ASSET4 } \\
\text { (Datastream) }\end{array}$ \\
\hline Legal system & LEG_SYST & $\begin{array}{l}\text { The legal system is a binary } \\
\text { variable that takes the value of } 1 \\
\text { if the company belongs to the } \\
\text { Anglo-Saxon legal system and } 0 \\
\text { otherwise. }\end{array}$ & $\begin{array}{l}\text { The annual } \\
\text { reports }\end{array}$ \\
\hline
\end{tabular}

Notes: This table reports the definitions of the variables used in our study.

*: The metals, chemicals, mining and industrial construction sectors are considered to have high social and environmental impacts (Pollutant sector), while new information technologies, service and trade sectors are associated with social and environmental problems hardly visible (No pollutant).

\subsection{Regression model}

Our research model was as follows:

$$
\begin{aligned}
& \text { DISC_SCORE }_{\mathrm{i}, \mathrm{t}}=\beta_{0}+\beta_{1} \text { VAIC }_{\mathrm{i}, \mathrm{t}}+\beta_{2} \mathrm{CSR}_{-} \mathrm{INDEX}_{\mathrm{i}, \mathrm{t}}+\beta_{3} \mathrm{VAIC}_{\mathrm{i}, \mathrm{t}}{ }^{*} \mathrm{CSR}_{-} \mathrm{INDEX}_{\mathrm{i}, \mathrm{t}}+\beta_{4} \mathrm{INVT}_{\mathrm{i}, \mathrm{t}}+\beta_{5} \mathrm{WOM}_{-} \mathrm{BD}_{\mathrm{i}, \mathrm{t}}+ \\
& \beta_{6} \mathrm{LEG}_{-} \mathrm{SYST}_{\mathrm{i}, \mathrm{t}}+\beta_{7} \mathrm{LEVE}_{\mathrm{i}, \mathrm{t}}+\beta_{8} \mathrm{POL}_{-} \mathrm{SECT}_{\mathrm{i}, \mathrm{t}}+\sum_{\mathrm{j}=9}^{13} \beta_{\mathrm{j}} \mathrm{YEAR}_{\mathrm{i}, \mathrm{t}}+\sum_{\mathrm{k}=14}^{17} \beta_{\mathrm{k}} \mathrm{COUNTRY}_{\mathrm{i}, \mathrm{t}}+\sum_{\mathrm{l}=18}^{43} \beta_{1} \operatorname{INDUSTRY}_{\mathrm{i}, \mathrm{t}}+\varepsilon_{\mathrm{i}, \mathrm{t}}
\end{aligned}
$$


All the variables are defined previously in Table 2. YEAR, COUNTRY and INDUSTRY stand respectively for year, country and industry fixed effects; $\varepsilon$ is the error term and the indices $i$ and $t$ represent respectively the companies and the year.

\section{Empirical results}

To test the different research hypotheses developed, we used bivariate statistical tests to test linear regression before performing the multivariate tests.

\subsection{Descriptive statistical analysis}

Table 3 summarizes the descriptive statistics of all the variables of our research model. As can be seen from this table, statistical tests show that companies of our study sample have a high level of voluntary IC disclosure. On average, this variable is equal to 0.59 with a relatively small standard deviation of 0.130 . This justifies that they tend to improve their information disclosure. Its minimum and maximum values are equal to 0.15 and 0.85 , respectively. This shows the diversity and heterogeneity of the sample in terms of voluntary IC disclosure level reported by these companies. Our results are in agreement with those found by Maaloul and Zégal (2015), who found a disclosure score of 0.46 for a sample of US companies in 2013. Furthermore, on average, the effect of the percentage of CSR on the voluntary IC disclosure is 0.698. As a result, the majority of companies in our sample are committed to CSR. Un score RSE plus élevé indique cependant que l'entreprise affiche une meilleure performance RSE (Hassan \& Guo, 2017). The mean value of VAIC in ESG firms is 14.094. We see that value added of intellectual capital in ESG firm's spans from a minimum of 2.3 to a maximum of 45.3 .

Likewise, for the control variables the following considerations may arise. This table shows that the average level of debt (LEVE) is equal to 0.333, which corresponds to an acceptable level of indebtedness. Its minimum and maximum values are 0.0705 and 0.7324 , respectively. The average percentage of representative women in the board (WOM_BD) is quite low (0.223) with minimum and maximum values of 0.10 and 0.429 , respectively. As a result, there is a predominance of men in the board of directors. We note that the innovation intensity (INVT) of the companies in our sample ranges between 0 and 0.844 with an average of 0.028 .

From the analysis of Panel B in Table 3, highlighting the binary variables relating frequencies, it can be noted that regarding the legal system (LEG_SYST) most of the sample companies turn out to pertain to the Anglo-Saxon rules (53\%). In addition, $51 \%$ of the companies in our sample belong to non-polluting sectors. It seems that our sample is evenly distributed. 
Does value added of intellectual capital influence voluntary disclosure?

The moderating effect of CSR practices

Table 3. Descriptive statistics

Panel A : Descriptive statistics for metric variables

\begin{tabular}{|c|c|c|c|c|c|}
\hline Variables & Observations & Mean & SD & Min & Max \\
\hline DISC_SCORE & 765 & 0.590 & 0,130 & 0.15 & 0.85 \\
\hline CSR_INDEX & 765 & 0.698 & 0.461 & 0.15 & 0.988 \\
\hline VAIC & 765 & 14.094 & 8.255 & 2.3 & 45.3 \\
\hline $\begin{array}{l}\text { CSR_INDEX* } \\
\text { VAIC }\end{array}$ & 765 & 12.731 & 7.883 & 2.231 & 43.438 \\
\hline INVT & 765 & 0.028 & 0.119 & 0 & 0.844 \\
\hline LEVE & 765 & 33.305 & 15.946 & 7.05 & 73.24 \\
\hline WOM_BD & 765 & 0.223 & 0.076 & 0.1 & 0.429 \\
\hline \multicolumn{6}{|c|}{ Panel B : Frequencies (\%) for binary variables } \\
\hline Variables & \multicolumn{3}{|c|}{ Modality } & \multicolumn{2}{|c|}{$\%$} \\
\hline \multirow[t]{2}{*}{ LEG_SYST } & \multicolumn{3}{|c|}{0} & \multicolumn{2}{|c|}{$47 \%$} \\
\hline & \multicolumn{3}{|c|}{1} & \multicolumn{2}{|c|}{$53 \%$} \\
\hline \multirow[t]{2}{*}{ POL_SECTOR } & & 0 & & \multicolumn{2}{|c|}{$51 \%$} \\
\hline & & 1 & & \multicolumn{2}{|c|}{$49 \%$} \\
\hline
\end{tabular}

Note: This table reports descriptive statistics. Variables definitions are provided in Table 2.

\subsection{Correlations analysis}

The main purpose of the test is to find whether any multicollinearity problems exist among the variables and also to reveal any association between them. According to Tabachnick et al. (2007), the problem prevails in the case when correlation values exceed 0.9 , i.e., whenever the independent variables turn out to be highly correlated among each other. Table 4 illustrates the correlation coefficients between dependent, independent and control variables.

The maximum value per pair in this study was 0.264 (Table 4); thus, multicollinearity should not be a concern for the regression analysis. We accept the null hypothesis of the autocorrelation; the fact that the explanatory variables are weakly correlated with each other indicates that autocorrelation is not a problem.

The Variance Inflation Factor (VIF) analysis revealed no evidence of multicollinearity as the VIF values for all independent variables ranged from 1.16 to 8.87, which are well below the upper acceptable limit of 10 . VIF has been reported for each regression to demonstrate the stability of the model. In fact, both tests suggest that regression estimates are not degraded by the presence of multicollinearity. 
Table 4. Pearson correlation matrix of variables and VIF values

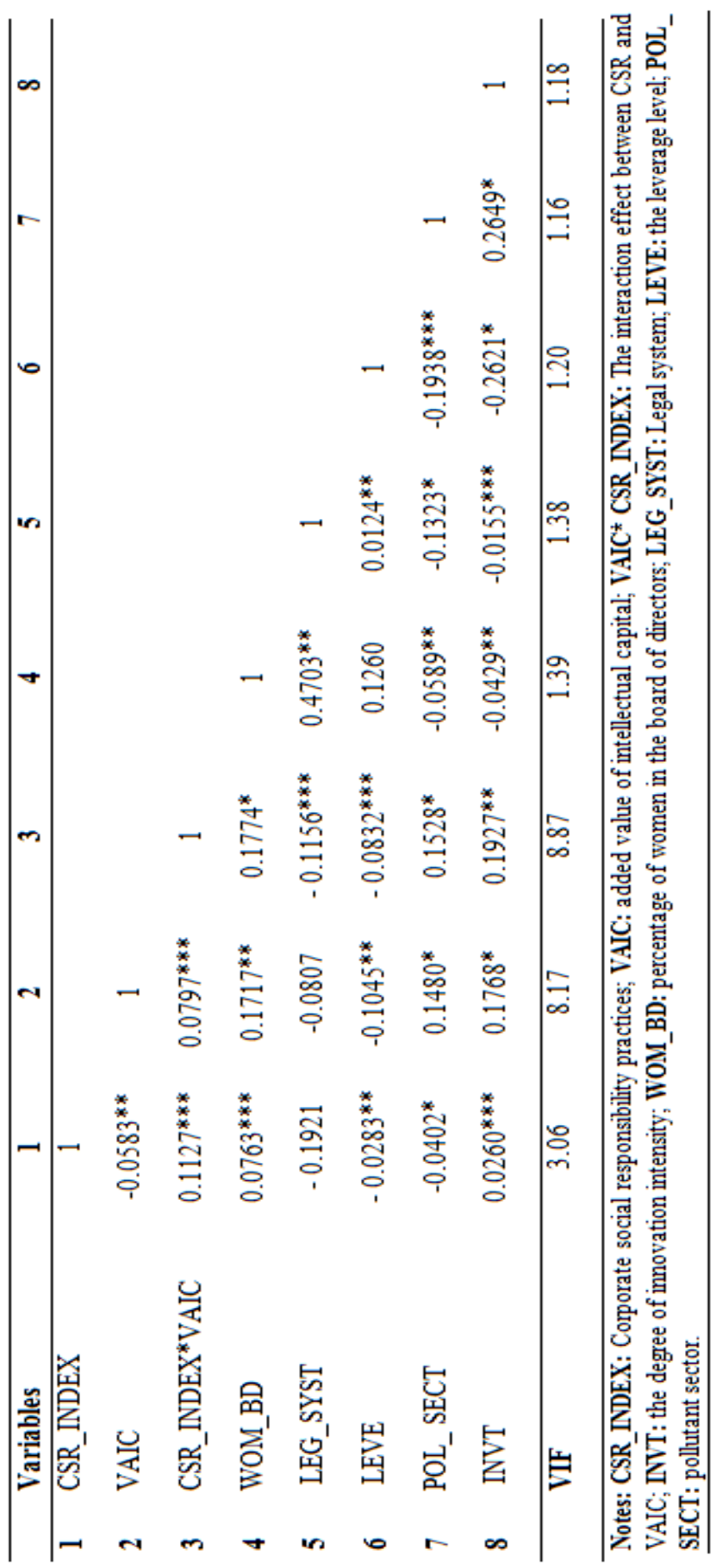




\subsection{Selection of fixed or random effect}

The decision of fixed and random effect lies on the result of Hausman's test. A Hausman test has been typically used to determine the consistency of the GLS estimator in static models with pooled cross-section-time-series data. This test when run for the data of present study gave significant result which proves the use of fixed effect regression analysis so for our model before regression analysis Hausman's test was run and for almost all model fixed effect was applied as per the results of Hausman's test.

Table 5 presents the decision of fixed effect lies on the result of Hausman's test:

Table 5. Hausman test

\begin{tabular}{llll}
\hline & $\chi 2(\boldsymbol{k})$ & $\boldsymbol{p}$-value & $\boldsymbol{F E} / \boldsymbol{R E}^{* *}$ \\
\hline Model & 129.38 & 0.000 & $F E$ \\
\hline Notes: $* *$ & FE/RE $:$ fixed or random effect $; \chi 2(k)>\chi 2$ (Hausman) & $\boldsymbol{R E} ; \chi^{2(k)}<\chi 2$ (Hausman) \\
$\boldsymbol{F E}$ & & \\
\hline
\end{tabular}

\subsection{Regression-analyses}

In this section, we proceed to our review of IC disclosure by distinguishing between two different scenarios, namely over-disclosure and under-disclosure, described by positive residues in the disclosure model. Table 6 presents the results of the estimation of our model. Indeed, the results show that the quality of the IC information disclosed necessarily depends on VAIC and CSR, because the quality coefficient of measurement is positive and significant $(p<0.1)$. These results are consistent with those reported by Bchini (2015) and Ozkan et al. (2016), and confirm our proposals, stating that better VAIC and better engagement in socially responsible practices help to improve the effectiveness and quality of disclosure. In addition, we are committed to testing the effect of the interaction between VAIC and CSR on IC disclosure. The interaction between these two variables was found to have a positive and significant coefficient, indicating that VAIC in the light of socially responsible practices decrease information asymmetry.

As expected, the attainted empirical findings prove evidence about supporting the research hypotheses. Thus, it can be concluded that the model is statistically significant and explanatory for the phenomenon under investigation. 
Table 6. Results of the multiple linear regressions model

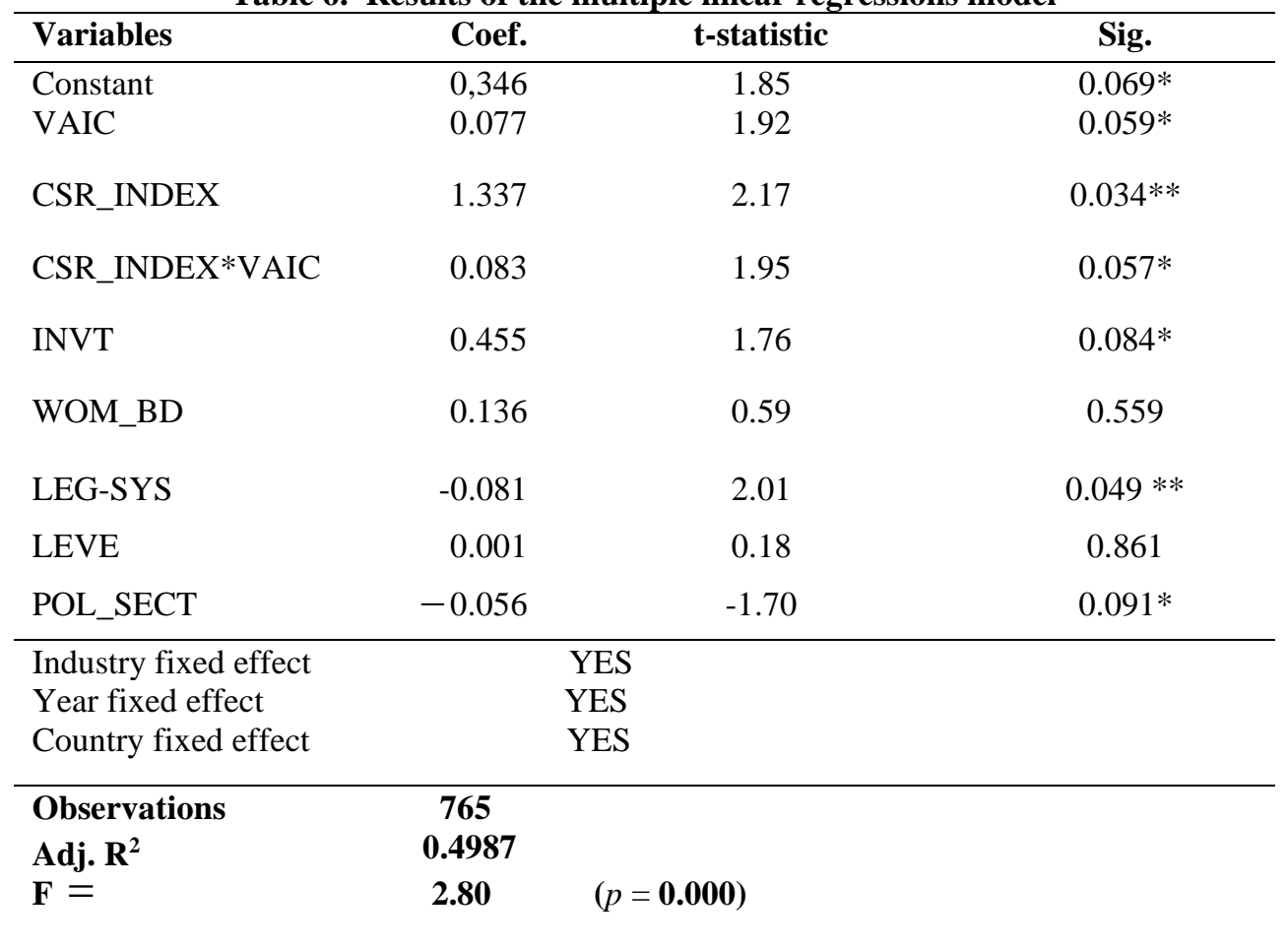

Notes: This table presents results from linear regressions in our model. t-Statistics estimator are reported in parentheses. Year, industry, and country indicators are included in our models, but their coefficients are not shown in this Table. The asterisks $* * *$ and $* *$ indicate significance at the $5 \%$ and $1 \%$ levels, respectively.

\section{Empirical tests and findings}

Table 6 depicts the results of panel data fixed effects regression estimates with observations from all the 5 years. These results highlight the determinants of IC disclosure. As indicated in the table, the model is highly significant (based on the F statistic) with an adjusted R2 equal to 0.4987. As predicted, the link between the existence of CSR practices and value added of intellectual capital in a company and the quality of IC disclosure is significant.

Therefore, hypothesis $\mathrm{H} 1$ is supported. This hypothesis was used to test whether the value added of intellectual capital of ESG firms has a positive influence on the level of voluntary IC disclosure. Examination of causality relationships shows that this variable has a positive and significant effect on the voluntary IC disclosure. This corroborates the predictions of hypothesis (H1). Based on the above, one may argue that value added of intellectual capital drive the acquisition and development of new 
transparency strategy in all its forms, that is human and relational capital voluntary disclosure.

The increasing importance of a company's intellectual capital is illustrated by empirical work such as that of Albertini and Fabienne (2019), who states that intellectual capital is 'becoming the preeminent resource for creating economic wealth'. Knowledge has become the key economic resource, and the dominant and perhaps even the only source of competitive advantage. The role of intellectual capital in creating value has become crucial in achieving a competitive advantage in the market (Barth, 2015). This intellectual capital relevance is also a determinant of this type of disclosure to reduce the asymmetry of information. One possible explanation of this result is that the presence of intellectual capital relevance within companies aims to implement a better information disclosure policy for stakeholders. Thus, our empirical evidence validates our view that increasing disclosure is a form of advantage related to the intellectual capital. The theory of legitimacy also has some ideas to offer regarding intellectual capital reputation and the effect of value added to this IC on the disclosure of this type of information. This theory can be considered as a systemic approach that considers businesses as part of a larger system. The basic idea underlying this research strand is that it is necessary to disclose information about intellectual capital, who is who is the hidden assets which traditional financial accounting fails to (fully) recognize. Our results are consistent with those of Salvia et al. (2020). These authors found considering that traditional financial disclosures do not contain IC-related information, various stakeholders have long asked companies to voluntarily disclose their intellectual resources for those to be incorporated into firm performance considerations and valuations.

Regarding the second hypothesis, integrating socially responsible practices into corporate strategy is likely to be a significant determinant of disclosure. This hypothesis asserts that CSR has a positive influence on the level of voluntary disclosure of intellectual capital. An examination of statistical tests shows that this variable positively and statistically influences the voluntary disclosure of information. Examination of the causality effect shows that the statistical coefficient associated with the variable "CSR_INDEX" has a positive value (1.337). The significance of these coefficients is obtained by Student's t-test $(\mathbf{t}=\mathbf{2 . 1 7}, \mathbf{p}=\mathbf{0 . 0 3 4})$. This means that CSR has a positive and significant effect on the voluntary IC disclosure thus corroborating hypothesis (H2). One argument is that firms should treat all stakeholders more or less equally and should make similar investments in different CSR activities (Ongsakul et al., 2020). In this respect, CSR is positively interpreted by the various stakeholders through its effects on the decisions made by the company and on the cognitive and mental schema of the leader as well as on the legitimacy of the decisions. 
In the same way, our results fit in perfectly with the conclusions of the current of legitimacy of the company's leader. Thus, in some cases, and on the basis of the postulates of the agency theory, the leader engaging in specific CSR-related activities aims at reducing asymmetric information through these actions. Indeed, our empirical results support our view that CSR reinforces the voluntary IC disclosure. These results suggest that there is a positive relationship between the level of disclosure and CSR and that increased disclosure is a form of socially responsible behavior. Therefore, firms should invest more in certain CSR activities than others, leading to higher CSR equality. Therefore, in a specific framework, such as developing a voluntary IC disclosure strategy, the company's engagement in corporate social responsibility activities is an asset that enhances investor confidence in the company's long-term strategy. In addition, comparable to the results of Areal and Carvalho (2012) on a sample of the most ethical companies in the world, our results confirm that the companies of our sample have a surplus of voluntary IC disclosure, which means that the social responsibility of these companies has provided a remarkable annual surplus of IC over what was expected and reduced the level of risk compared with other companies. In addition, as shown by GarcíaSánchez et al. (2016), the company's commitment to social responsibility activities can affect the level of voluntary disclosure and promote financial transparency. In other words, engagements in CSR activities dominated by the strategy of transparency and reliability have a significant effect on voluntary disclosure. In order to verify whether these results are solid, we measured the relationship between these two variables and compared them to previous results. Our empirical evidence corroborates the results of previous studies (Karim et al., 2016; Martínez-Ferrero et al., 2016; Elvira et al., 2016; Fatemi et al., 2017; Wellalage et al., 2019), and validates our second hypothesis.

The integration of socially responsible practices into the value creation strategy by intellectual capital is likely to be a significant determinant of IC information disclosure. Therefore, the third hypothesis stipulates that the interaction between the socially responsible practices and VAIC of companies engaged in the societal approach is a determining factor of information disclosure. The examination of the causal effect shows that the statistical coefficient associated with the interaction between the VAIC and the socially responsible practices "CSR_INDEX * VAIC" has a positive $(\mathbf{0 . 0 8 3})$ and statistically significant value at the level of $1 \%(\mathrm{t}=\mathbf{1 . 9 5}$, $\boldsymbol{p}$ 0.057). Our results highlight the importance of social responsibility practices as a determinant of the relationship between a strategy of transparency and VAIC. The objective of our work was to propose the integration of two complementary statements in IC information: namely the social practices and the intellectual capital report. Our results are in line with most theoretical and empirical studies on this topic. For example, Archel et al. (2009) recognize that CSR actions are a concern for sustainability which have been integrated into the strategic processes, such as transparency and disclosure of information, in order to ensure the creation of value. 
In addition, Polo and Vázquez (2008) found that there is an overlap of content and objectives between social relations and the report on intellectual capital. For instance, information of a social nature is dealt with in the different blocks of analysis of intangibles in the IC report. Furthermore, these disclosures share the direct or indirect goals of improving the company's corporate image, which also reflects the links between the two types of reports. Hence, given the observed similarities and the greater flexibility and scope of the IC report, these authors propose to incorporate the IC report into the social report. The benefits will be twofold: a reduction in the direct costs of preparing the report and a simplification of the non-financial information for the different stakeholders.

Turning to the control variables, we find that most of their coefficients have the expected signs. The degree of innovation intensity (INVT) is positively and significantly $(\mathrm{p}<10 \%)$ associated with voluntary disclosure of intellectual capital. This finding suggests that the most innovative firms worldwide have adopted more voluntary disclosure practices about intellectual capital; in fact, innovative firms are often under greater pressure from the part of investors and financial analysts to disclose intellectual capital relating information. In addition, the legal system relevant to each country (LEG_SYST) is involved in controlling for the corporate transparency: it is also worth highlighting that the legal system appears to be negatively correlated and statistically significant $(\mathrm{p}<5 \%)$ with voluntary disclosure of intellectual capital. Differently from what expected, the legal system helps in reinforcing potential conflicts of interest and information asymmetry. Additionally, the influence of pollutant sector (POL_SECTOR) turns out to be negatively and significantly correlated $(\mathrm{p}<10 \%)$ with the voluntary disclosure of intellectual capital, as expected. Similarly, the level of indebtedness and percentage of women on boards of directors present directions that are contrary to what expected.

\section{Robustness analyses}

To test the robustness of the results, multiple regressions were performed for voluntary disclosure of intellectual capital by using two types of legal system. As indicated in Table 7, the results using lagged data appear in a pattern very similar to the original multiple regression results shown in Table 6 . This result specifically demonstrates that there is no significant difference in the legal and institutional framework between the two types of legal system in question. Our results are very interesting for regulators if we do country-by-country analysis and allow us to generalize our results a bit in the World context. 
Table 7. Multi-variable estimation regression results

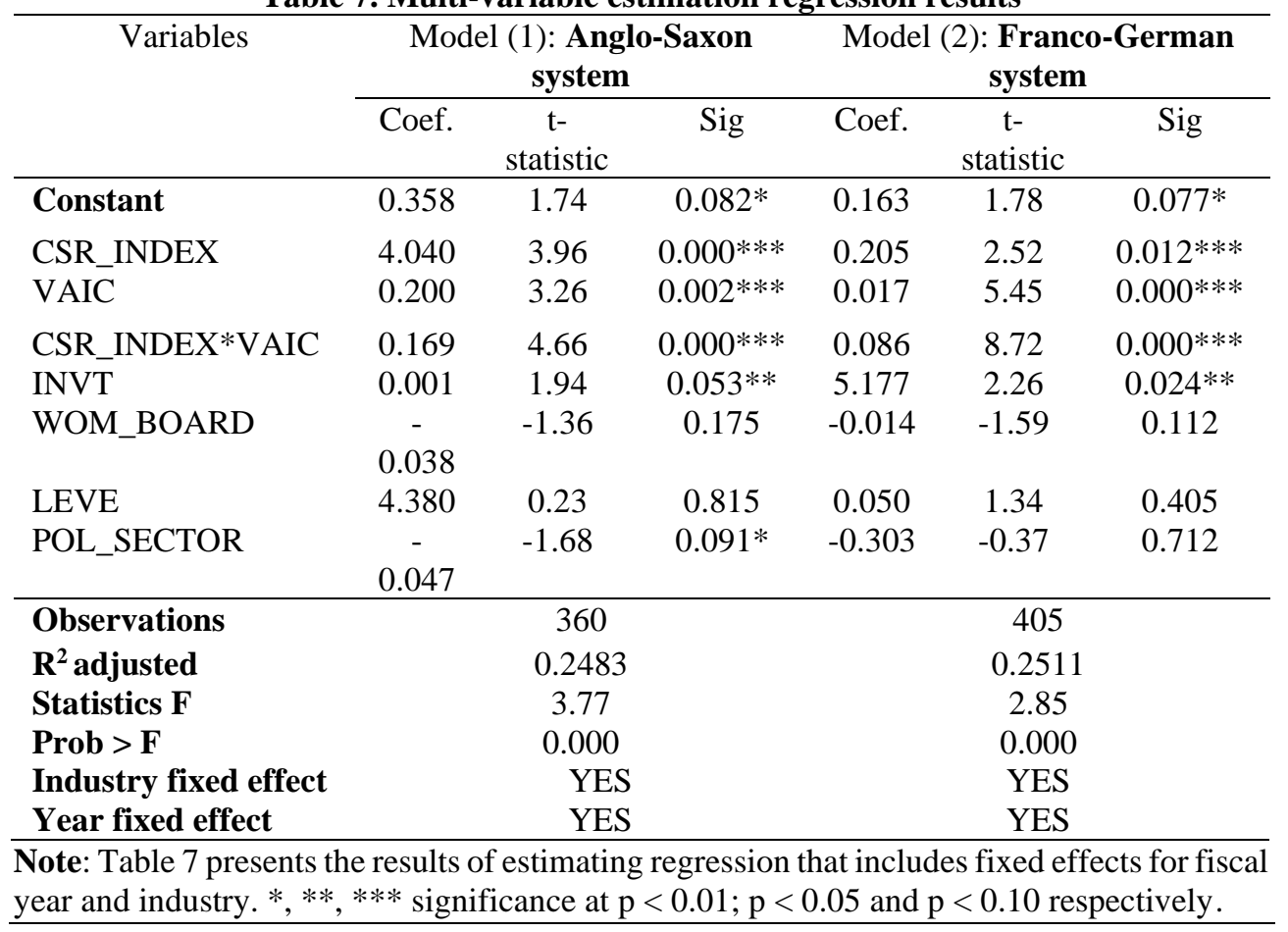

\section{Conclusion}

The present paper addresses, through an empirical approach, the effect of CSR practices and VAIC on IC disclosure, by examining whether and how CSR practices affect the relation between VAIC and IC disclosure in the ESG Company. The overall results reached through the research show some applicative potential. This study is a good reference on the fundamental role of the societal practices in improving the process of voluntary IC disclosure, as well as on the quality and relevance of the information disclosed. This work is conceived as an extension of this research topic by attempting to document and formulate a conclusion on the fundamental role of the social approach in improving the disclosure process. Corporations invest billions of dollars in several CSR activities, some related to the environment, others to employee relations or diversity (Brieger et al., 2019; Ongsakul et al., 2020).

Companies' CEOs can benefit from the fundamental understanding of the importance of socially responsible practices in developing a policy of voluntary IC disclosure within a context characterized with a new tendency of companies to be responsible in this respect. Indeed, the lack of information dissemination on intangible capital by companies may create an underestimation of the value of these 
assets. Accordingly, transparency, approximated by IC disclosure, is strongly and positively correlated with the added value and the CSR practices. Voluntary disclosure on the intangibles can thus help establish a better perception of the real value of the company by the investors as it allows, particularly, explaining the significant gap between the book value of companies and their stock prices and thus attracting new investors. In accordance with our research hypotheses, VAIC plays a positive and significant role in the voluntary disclosure of intellectual capital. In other words, the most successful ESG companies in the CSR practices disclose more information about their IC. In addition, the commitment of the company to socially responsible practices is a determinant of the voluntary IC disclosure.

In other words, and as our results indicate, financial transparency constitutes a necessary condition for an effective promotion of an ESG company involved in the social responsibility (CSR) practices. The quality of information disclosed about the ESG Company's intellectual capital based on a set of social should necessarily help improving the firm's social legitimacy (Akisik \& Gal, 2017; Zhao et al., 2018). The conformity between the results obtained and our assumptions is justified by the fact that the commitment in the activities of social responsibility is an asset for companies adapting a strategy of transparency and reliability. We can also conclude that the interaction between socially responsible practices and the VAIC is positively and significantly associated with the strategy of transparency and voluntary IC disclosure. In this regard, it is argued that socially responsible corporate behavior is a moderating factor in the relationship between the voluntary IC disclosure and VAIC.

Like any research, our study has some limitations. Indeed, the fact that our sample encompasses several different business sectors and research contexts in which the value added by IC differs from one sector of activity to another, the present work does not claim to give a complete and exhaustive answer to the concepts studied. Therefore, to improve this line of research, future research must deepen and enrich the different scales of our explanatory variables to specify the effect of each variable in each sector separately. In other words, it would be interesting to test our model in specific sectors of activity as our sample is heterogeneous.

\section{References}

Abeysekera, I. (2008) "Intellectual capital disclosure trends: Singapore and Sri Lanka", Journal of Intellectual capital, vol. 9, no. 4: 723-737.

Abeysekera, I. (2011) "The relation of intellectual capital disclosure strategies and market value in two political settings", Journal of Intellectual Capital, vol. 12, no. 2: 319-338. 
Akisik, O. \& Gal, G. (2017) "The impact of corporate social responsibility and internal controls on stakeholders' view of the firm and financial performance", Sustainability Accounting, Management and Policy Journal, vol. 8, no. 3: 246-280.

Albertini, E. \& Fabienne B. (2019) "Intellectual capital and financial performance: A meta-analysis and research agenda", $M @ n @$ gement, vol. 22, no. 2: 216-249

Alipour, M. Ghanbari, M. Jamshidinavid, B. \& Taherabadi, A. (2019) "The relationship between environmental disclosure quality and earnings quality: a panel study of an emerging market", Journal of Asia Business Studies, vol. 13 , no. 2: 326-347

Archel, P., Husillos, J., Larrinaga, C. \& Spence, C. (2009) "Social disclosure, legitimacy theory and the role of the state", Accounting, auditing \& accountability journal, vol. 22, no. 8: 1284-1307

Areal, N. \& Carvalho, A. (2012) "The financial performance of the World's Most Ethical Companies: advantage in times of crisis", Available at SSRN 2186088.

Ashton, R. H. (2005) "Intellectual capital and value creation: a review", Journal of Accounting Literature, vol. 24: 53-134

Ball, R. Li, X. \& Shivakumar, L. (2015) "Contractibility and transparency of financial statement information prepared under IFRS: Evidence from debt contracts around IFRS adoption", Journal of Accounting Research, vol. 53, no. 5: 915-963

Barker, III. V. L. \& Mueller, G. C. (2002) "CEO characteristics and firm R\&D spending”, Management Science, vol. 48, no. 6: 782-801

Barniv, R. \& Myring, M. (2006) "An international analysis of historical and forecast earnings in accounting-based valuation models", Journal of Business Finance \& Accounting, vol. 33, no. 7-8: 1087-1109

Barth, M. E. (2015) "Financial accounting research, practices, and financial accountability", Abacus, vol. 51, no. 4: 499-510

Barth, M. Kasznik, R. \& McNichols M. (2001) "Analyst coverage and intangible assets", Journal of Accounting Research, vol. 39, no. 1: 1-34

Bchini, B. (2015) "Intellectual capital and value creation in the Tunisian manufacturing companies", Procedia Economics and Finance, vol. 23: 783-791

Bebbington, J., Larrinaga, C. \& Moneva, J. M. (2008) "Corporate social reporting and reputation risk management", Accounting, Auditing \& Accountability Journal, vol. 21, no. 3: 337-361

Berzkalne, I. \& Zelgalve, E. (2014) "Intellectual capital and company value", Procedia-Social and Behavioral Sciences, vol. 110: 887-896

Botosan C. A. (2006) "Disclosure and the cost of capital: what do we know?", Accounting and Business Research, vol. 36, no. 1: 31-40

Brammer, S., \& Pavelin, S. (2004) "Building a good reputation", European Management Journal, vol. 22, no. 6: 704-713 
Brieger S. A. Francoeur C., Welzel C. \& Ben-Amar W (2019) "Empowering women: The role of emancipative forces in board gender diversity", Journal of Business Ethics, vol. 155, no. 2: 495-511

Campbell K. \& Mínguez-Vera, A. (2008) "Gender diversity in the boardroom and firm financial performance", Journal of Business Ethics, vol. 83, no. 3: 435-451

Chan, A. L., Lee, E., \& Lin, S. (2009) "The impact of accounting information quality on the mispricing of accruals: The case of FRS3 in the UK", Journal of Accounting and Public Policy, vol. 28, no. 3: 189-206

Chen Goh, P. (2005) "Intellectual capital performance of commercial banks in Malaysia", Journal of Intellectual Capital, vol. 6, no. 3: 385-396

Choi, J. J., Jo, H., Kim, J. \& Kim, M S. (2018) "Business groups and corporate social responsibility", Journal of Business Ethics, vol. 153, no. 4: 931-954

Dias, A., Rodrigues, L. L., \& Craig, R. (2017) "Corporate governance effects on social responsibility disclosures", Australasian Accounting Business and Finance Journal, vol. 11, no. 2: 3-22

Elvira, Q., Beausaert, S., Segers, M., Imants J. \& Dankbaar, B (2016) “Development and validation of a Supportive Learning Environment for Expertise Development Questionnaire (SLEED-Q)", Learning Environments Research, vol. 19, no. 1: 17-41

Fassin, Y., Werner, A., Van Rossem, A., Signori, S., Garriga, E., von Weltzien Hoivik, H., \& Schlierer, H. J. (2015) "CSR and related terms in SME ownermanagers' mental models in six European countries: National context matters", Journal of Business Ethics, vol. 128, no. 2: 433-456

Fatemi, A., Glaum, M., \& Kaiser, S. (2017) "ESG performance and firm value: The moderating role of disclosure", Global Finance Journal, vol. 38: 45-64

Ferchichi, J., \& Paturel, R. (2013) "The effect of intellectual capital disclosure on the value creation: An empirical study using Tunisian annual reports", International Journal of Accounting and Financial Reporting, vol. 3, no. 1: 81

Firer, S.. Y. \& Williams, S. M. (2003) "Intellectual capital and traditional measures of corporate performance", Journal of Intellectual Capital, vol. 4, no. 3: 348360

Freedman, M. \& Jaggi, B. (2005) "Global warming, commitment to the Kyoto protocol, and accounting disclosures by the largest global public firms from polluting industries", The International Journal of Accounting, vol. 40, no. 3: 215-232

Gamerschlag, R., Möller, K. \& Verbeeten, F. (2011) Determinants of voluntary CSR disclosure: empirical evidence from Germany", Review of Managerial Science, vol. 5, no. 2-3: 233-262

García-Sánchez, I. M., Cuadrado-Ballesteros, B. \& Frias-Aceituno, J. V. (2016) "Impact of the institutional macro context on the voluntary disclosure of CSR information", Long Range Planning, vol. 49, no. 1: 15-35 
Gery Djajadikerta, H. \& Trireksani, T. (2012) "Corporate social and environmental disclosure by Indonesian listed companies on their corporate web sites", Journal of Applied Accounting Research, vol. 13, no. 1: 21-36.

Hu, Z., Cai, W., Han, J. \& Sa, R. (2012) "An empirical study of the effect of venture capital participation on the accounting information quality of IPO firms", China Journal of Accounting Research, vol. 5, no. 3: 251-268.

Jamali, D. \& Mirshak, R. (2007) "Corporate social responsibility (CSR): Theory and practice in a developing country context", Journal of Business Ethics, vol. 72, no. 3: 243-262

Jensen, M.C., (2002) "Value maximization, stakeholder theory, and the corporate objective function", Business Ethics Quarterly, vol. 12: 235-256

Karim, K., Suh, S. \& Tang, J. (2016) "Do ethical firms create value?", Social Responsibility Journal, vol. 12, no. 1: 54-68

Lambert, R. A., Leuz, C., \& Verrecchia, R. E. (2011) "Information asymmetry, information precision, and the cost of capital", Review of Finance, vol. 16, no. 1: $1-29$

Lev, B., Cañibano, L. \& Marr, B. (2005) "An accounting perspective on intellectual capital”, In Marr, B. (Ed.) Perspectives on intellectual capital, pp. 42-55

Li, J., Pike, R. \& Haniffa, R. (2008) "Intellectual capital disclosure and corporate governance structure in UK firms", Accounting and Business Research, vol.38, no. 2: 137-159

Liang, H., \& Renneboog, L. (2017) "On the foundations of corporate social responsibility", The Journal of Finance, vol. 72, no. 2: 853-910

Lin, C. S., Chang, R. Y. \& Dang, V. T. (2015) "An integrated model to explain how corporate social responsibility affects corporate financial performance", Sustainability, vol. 7, no. 7: 8292-8311

Luthan, E. \& Asniati Yohana, D. (2016) "A correlation of CSR and intellectual capital, its implication toward company's value creation", International Journal of Business and Management Invention, vol. 5, no. 11: 88-94

Maaloul, A. \& Zeghal, D. (2015) "Financial statement in formativeness and intellectual capital disclosure: an empirical analysis", Journal of Financial Reporting and Accounting, vol. 13, no. 1: 66-90

Martínez-Ferrero, J., Banerjee, S. \& García-Sánchez, I. M. (2016) “Corporate social responsibility as a strategic shield against costs of earnings management practices", Journal of Business Ethics, vol. 133, no. 2: 305-324

Mohammad, H. S. \& Bujang, I. (2019) "Performance of Malaysian financial firms: An intellectual capital perspective using MVAIC Model", Asian Economic and Financial Review, vol. 9, no. 7: 752-765

Murashima, M. (2020) "Do investors' reactions to CSR-related news communication differ by shareholder? An empirical analysis from Japan", Corporate Governance: The International Journal of Business in Society, vol. 20: 781-796 
Ongsakul, V., Jiraporn, N. \& Jiraporn, P. (2020) "Exploring how independent directors view CSR inequality using a quasi-natural experiment", Corporate Governance, vol. 20, no. 6: 1159-1172

Özer, G. \& Çam, İ. (2016) "The role of human capital in firm valuation: an application on BIST", Procedia-Social and Behavioral Sciences, vol. 235: $168-177$

Ozkan, N., Cakan, S. \& Kayacan, M. (2017) "Intellectual capital and financial performance: A study of the Turkish Banking Sector", Borsa Istanbul Review, vol. 17 , no. 3: 190-198

Peters, G. F. \& Romi, A. M. (2013) "Discretionary compliance with mandatory environmental disclosures: Evidence from SEC filings", Journal of Accounting and Public Policy, vol. 32, no. 4: 213-236

Polo, F. C. \& Vázquez, D. G. (2008) "Social information within the intellectual capital report", Journal of International Management, vol. 14, no. 4: 353-363

Pulic, A. (1998) "Measuring the performance of intellectual potential in knowledge economy", In 2nd McMaster Word Congress on Measuring and Managing Intellectual Capital by the Austrian Team for Intellectual Potential, 1-20

Pulic, A. (2000) "VAIC" journal of technology management, vol. 20, no. 5-8: 702-714

Said, R., Zainuddin, Y.H. \& Haron, H. (2009) "The relationship between corporate social responsibility disclosure and corporate governance characteristics in Malaysian public listed companies”, Social Responsibility Journal, 5, no. 2: 212-226

Salvi, A., Vitolla, F., Giakoumelou, A., Raimo, N. \& Rubino, M. (2020) "Intellectual capital disclosure in integrated reports: The effect on firm value", Technological Forecasting and Social Change, no. 160: 120228

Seleim, A., Ashour, A. \& Bontis, N. (2004) "Intellectual capital in Egyptian software firms", The Learning Organization, vol. 11, no. 4-5: 332-346

Škare, M., \& Golja, T. (2014) "The impact of government CSR supporting policies on economic growth", Journal of policy modeling, vol. 36, no. 3: 562-577

Stubbs, W. \& Rogers, P. (2013) "Lifting the veil on environment-social-governance rating methods", Social Responsibility Journal, vol. 9, no. 4: 622-640

Su, W., Peng, M. W., Tan, W. \& Cheung, Y. L. (2016) "The signaling effect of corporate social responsibility in emerging economies", Journal of business Ethics, vol. 134, no. 3: 479-491

Sun, N., Salama, A., Hussainey, K. \& Habbash, M. (2010) "Corporate environmental disclosure, corporate governance and earnings management", Managerial Auditing Journal, vol. 25, no. 7: 679-700

Sutantoputra, A. W., Lindorff, M. \& Johnson, E. P. (2012) "The relationship between environmental performance and environmental disclosure", Australasian Journal of Environmental Management, vol. 19, no. 1: 51-65

Tabachnick, B. G., Fidell, L. S. \& Ullman, J. B. (2007) Using multivariate statistics, (5) Boston, MA: Pearson. 
Thorpe, D. (2013) Why CSR? "The benefits of corporate social responsibility will move you to act", Retrieved January, 12, 2014.

Vitolla, F., Raimo, N. \& Rubino, M. (2020) "Board characteristics and integrated reporting quality: an agency theory perspective", Corporate Social Responsibility and Environmental Management, vol. 27, no. 2: 1152-1163

Vitolla, F., Raimo, N., Rubino, M., \& Garzoni, A. (2019) "How pressure from stakeholders affects integrated reporting quality", Corporate Social Responsibility and Environmental Management, vol. 26, no. 6: 1591-1606

Wellalage, N. H., Locke, S. \& Samujh, H. (2019) "Corruption, gender and credit constraints: Evidence from South Asian SMEs", Journal of Business Ethics, vol. 159 , no. 1: $267-280$

Wong, A. K. F. \& Kim, S. S. (2020) "Development and validation of standard hotel corporate social responsibility (CSR) scale from the employee perspective", International Journal of Hospitality Management, 87: 102507

Zeghal, D. \& Maaloul, A. (2010) "Analysing value added as an indicator of intellectual capital and its consequences on company performance", Journal of Intellectual capital, vol. 11, no. 1: 39-60

Zhao, C., Guo, Y., Yuan, J., Wu, M., Li, D., Zhou, Y. \& Kang, J. (2018) "ESG and corporate financial performance: Empirical evidence from China's listed power generation companies", Sustainability, vol. 10, no. 8: 2607

\section{Appendix A: IC categories and subcategories (items)}

\begin{tabular}{|l|l|l|}
\hline Human capital & Structural capital & Relational capital \\
\hline 1. Number of employees & 1. Intellectual property & 1. Customers \\
2. Employee age & 2. Process & 2. Market presence \\
3. Employee diversity & 3. Management philosophy & 3. Customer relationships \\
4. Employee equality & 4. Corporate culture & 4. Customer acquisition \\
5. Employee relationship & 5. Organization flexibility & 5. Customer retention \\
6. Employee education & 6. Organization structure & 6. CTE \\
7. Skills/know-how & 7. Organization learning & 7. Customer involvement \\
8. Employee work-related & 8. Research \& development & 8. Company \\
competences & (R\&D) & image/reputation \\
9. Employee work-related & 9. Innovation & 9. Company awards \\
knowledge & 10. Technology & 10. Public relation \\
10. Employee & 11. Financial dealings & 11. Diffusion \& \\
attitudes/behavior & 12. Customer support & networking \\
11. Employee & function & 12. Brands \\
commitments & 13. Knowledge-based & 13. Distribution channels \\
12. Employee motivation & infrastructure & 14. Relationship with \\
13. Employee productivity & 14. Quality management \& & suppliers \\
\hline
\end{tabular}


Does value added of intellectual capital influence voluntary disclosure?

The moderating effect of CSR practices

\begin{tabular}{|c|c|c|}
\hline $\begin{array}{l}\text { 14. Employee training } \\
\text { 15. Vocational } \\
\text { qualifications } \\
\text { 16. Employee } \\
\text { development } \\
\text { 17. Employee flexibility } \\
\text { 18. Entrepreneurial spirit } \\
\text { 19. Employee capabilities } \\
\text { 20. Employee teamwork } \\
\text { 21. Employee involvement } \\
\text { with community } \\
\text { 22. Other employee } \\
\text { features }\end{array}$ & $\begin{array}{l}\text { improvement } \\
\text { 15. Accreditations } \\
\text { (certificate) } \\
\text { 16. Overall } \\
\text { infrastructure/capability } \\
\text { 17. Networking } \\
\text { 18. Distribution network }\end{array}$ & $\begin{array}{l}\text { 15. Business collaboration } \\
\text { 16. Business agreements } \\
\text { 17. Favorite contract } \\
\text { 18. Research } \\
\text { collaboration } \\
\text { 19. Marketing } \\
\text { 20. Relationship with } \\
\text { stakeholders } \\
\text { 21. Market leadership }\end{array}$ \\
\hline
\end{tabular}

(Source: Maaloul \& Zeghal, 2015)

\section{Appendix B: CSR composition (ASSET4)}

\begin{tabular}{|c|c|c|}
\hline & Pillars & Categories \\
\hline \multirow[t]{3}{*}{ CSR } & $\begin{array}{l}\text { Corporate governance Performance (5 } \\
\text { categories) }\end{array}$ & $\begin{array}{l}\text { Board structure (11 items) } \\
\text { Compensation policy } \\
\text { items) } \\
\text { Board functions (13 items) } \\
\text { Shareholders rights ( } 34 \text { items) } \\
\text { Vision and strategy (10 items) }\end{array}$ \\
\hline & $\begin{array}{l}\text { CSR_E (environmental) performance (3 } \\
\text { categories) }\end{array}$ & $\begin{array}{l}\text { Resource reduction (32 items) } \\
\text { Emission reduction (41 items) } \\
\text { Product innovation ( } 25 \text { items) }\end{array}$ \\
\hline & $\begin{array}{l}\text { CSR_S (society) performance }(7 \\
\text { categories) }\end{array}$ & $\begin{array}{l}\text { Employment quality (11 } \\
\text { items) } \\
\text { Health and safety (26 items) } \\
\text { Training and development (8 } \\
\text { items) } \\
\text { Diversity (11 items) } \\
\text { Human rights (13 items) } \\
\text { Corporate community } \\
\text { involvement (30 items) } \\
\text { Product responsibility } \\
\text { items) }\end{array}$ \\
\hline
\end{tabular}

(Source: Choi et al., 2018)

Vol. 19, No. 4 